\title{
The amount of monounsaturated, polyunsaturated, and saturated fatty acids in the diet of fifteen-year-olds boys and girls in correlation with body mass index values
}

\author{
Wioletta Waksmańska', Rafał Bobiński ', Anna Pielesz², Mieczysław Dutka', Tomasz llczak ${ }^{1}$ \\ ${ }^{1}$ Faculty of Health Sciences, University of Bielsko-Biala, Poland \\ ${ }^{2}$ Faculty of Materials, Civil and Environmental Engineering, University of Bielsko-Biala, Poland
}

\section{ABSTRACT}

\begin{abstract}
Aim of the study: A change in dietary habits affects the biochemical composition of the diet, including the amount of fatty acids and their mutual proportions. The aim of this study was to assess the intake of fatty acids by 15 -year-olds in correlation with body mass index (BMI) values.

Material and methods: The study covered a group of 76 boys and 57 girls who were third-year middle-school pupils in Poland. The included a 7-day dietary record for the assessment of the intake of nutrients, energy, and fatty acids using the DIETA FAO.

Results: The results show varied intake of energy and individual fatty acids by children relative to their division into groups depending on BMI values. Boys within the $5^{\text {th }}$ to $85^{\text {th }}$ BMI percentile bracket had the lowest intake of saturated fatty acids. The highest intake of monounsaturated and polyunsaturated fatty acids was observed among boys in group with the highest BMI percentile. In girls, the lowest intake of saturated fatty acids was in the group of girls below the $5^{\text {th }}$ percentile.

Conclusions: The normal dietary intake of fatty acids n-3 and n- 6 occurred amongst 15 -year-old boys and girls with BMI below the $5^{\text {th }}$ percentile. In order to achieve a properly balanced diet, it is necessary to increase the intake of monounsaturated fatty acids and reduce the intake of saturated fatty acids at the same time.
\end{abstract}

\section{KEY WORDS:}

adolescent, BMI, monounsaturated fatty acids (MUFA), polyunsaturated fatty acids (PUFA), saturated fatty acids (SFA).

\section{INTRODUCTION}

A change in dietary habits affects the biochemical composition of the diet, including the amount of fatty acids and their mutual proportions. When the intake of fatty acids (FAs) does not match physiological needs, this leads to BMI deviations and various metabolic complications. The BMI values are influenced by a number of other variables, such as sedentary lifestyle and low physical activity [1-3], and daily meal schedule, in particular the consumption of high energy foods in the evening and at night [4], as well as the amount of proteins, fats, and carbohydrates in the daily diet [5-8].

Fatty acids are essential substances. They participate in energy processes, the metabolism of proteins and sugars, and the control of gene expression; furthermore, they are precursors of prostacyclins, prostaglandins, thromboxanes, and leukotrienes $[9,10]$.

Long-chain polyunsaturated fatty acids (LCPUFA) are assigned a particular role [11-13]; they are believed to have protective properties for human health by influencing immunological reactions, protecting from allergies [14].

\section{ADDRESS FOR CORRESPONDENCE:}

Dr. Wioletta Waksmańska, Faculty of Health Sciences, University of Bielsko-Biala, Willowa 2, 43-309 Bielsko-

Biala, Poland, e-mail: wwaksmanska@ath.bielsko.pl 
The proportion of $n-6$ family FAs to $n-3$ family FAs in the diet can determine the stimulation or suppression of important bodily physiological processes (proliferation, infections, the activity of transcription factors, the tendency for mutagenesis, apoptosis, etc.) $[15,16]$.

As far as the physiological needs of the child are concerned, the second most important group of fatty acids present in the diet are MCFAs (medium-chain fatty acids), mainly $10: 0,12: 0$, and $14: 0$, which stabilise the bacterial flora in the child's digestive system, influence acylation and myristoylation of protein, are subject to quick oxidation [17-21]. Recent research indicates that fatty acids, especially long-chain polyunsaturated fatty acids, inhibit carcinogenesis [16].

An insufficient amount of fatty acid in the diet is caused principally by worldwide changes in dietary habits, the so-called western diet. This diet is characterised by high intakes of saturated fatty acids and sucrose as well as low intakes of dietary fibre, posing a risk for health by the increase of metabolic diseases incidence [22]. Insufficient supply of FAs leads to numerous metabolic changes and the occurrence of conditions such as diabetes and cardio-vascular illness - even in the distant future.

Excess weight and the related quality of nutrition are key public health problems around the world, which have grown particularly quickly in recent years. The aetiology is complex; however, one important factor is the change of dietary habits in western culture $[15,23,24]$.

During adolescence the eating habits of youths may change. This change results from the impact of TV commercials, attempts to be liked by their peers, or an increased amount of time spent eating meals with friends in fast-food restaurants. It is of interest to know whether changes taking place in the life of a 15-yearold person can influence the fatty acid content in his/ her diet [25].

The aim of the study was to assess the intake of fatty acids by 15 -year-olds in correlation with BMI values.

\section{MATERIAL AND METHODS}

The research was conducted in February 2018 in a typical middle school in the village in the region Podbeskidzie in Poland. The study covered all third-year middle-school pupils. Participation in the study was voluntary. Permission for the research was obtained from the children and their parents. In total, the research included 133 pupils at the age of 15 years ( 57 girls and 76 boys), which accounted for around $22 \%$ of the pupils living in the village aged $7-18$ years.

\section{GATHERING AND ASSESSMENT OF DATA}

With the assistance of the authors conducting the research, a validated questionnaire, employed al- ready in other research on large groups of children [26], was filled in, addressing the consumption of food products consumed every day for a period of 7 days. All children were tested simultaneously. The parents and adolescents were trained in correctly assessing the size of portions of foodstuffs consumed. During the assessment of food consumption, units of measurement such as millilitres, grams, mugs, and spoonful were used. The size of portions consumed was additionally checked using 'The Album of Photographs of Food Products and Dishes' [27].

To ascertain the number/amount of kilocalories, fatty acids, fat, proteins, and carbohydrates consumed daily, the DIETA FAO programme was used. The programme contains data on 1067 typical food products. A precise description of similar research using this programme has been included in earlier publications [28].

The questionnaire also took into account the results of anthropometric measurements of the adolescents taken by the researcher. BMI values were calculated for all the children, with these values classified according to the recommendations of the WHO: a BMI below the $5^{\text {th }}$ percentile - underweight; a BMI between the $5^{\text {th }}$ and $85^{\text {th }}$ percentile - appropriate body mass; and a BMI above the $85^{\text {th }}$ percentile - excess body weight [29]. Energy requirements for the analysed population were determined individually for each child, taking into account the child's gender and body weight as well as the average physical activity specified for the Polish population [30].

The financial situation of the study participants was declared by their parents and was measured on a 5-degree scale:

- very good - the money is sufficient to cover all the costs without saving,

- good - living economically and being able to afford everything,

- mediocre - living economically but having some problems with larger purchases,

- bad - the money is sufficient to buy the cheapest food and clothing,

- very bad - there is not enough money for the cheapest food or for clothes [26].

Physical activity was defined as the average amount of time spent on curricular and extracurricular physical activities during the week when the participants completed the questionnaire. Participants' parents declared the time spent on physical activity, which was checked against the number of obligatory physical education lessons.

\section{STATISTICAL ANALYSIS}

All calculations were made using the PQStat program (version 1.6.6). A significance level of $p<0.01$ was assumed in the analysis. The statistical analysis included 
TABLE 1. Presentation of the study group

\begin{tabular}{|c|c|c|c|c|c|}
\hline \multirow{2}{*}{$\begin{array}{l}\text { Parameter } \\
\text { Age (years) }\end{array}$} & \multirow[b]{2}{*}{ Mean (SD) } & \multicolumn{2}{|c|}{ Boys $(n=76)$} & \multicolumn{2}{|c|}{ Girls $(n=57)$} \\
\hline & & 15.2 & 0.2 & 15.1 & 0.3 \\
\hline \multicolumn{6}{|l|}{ SES } \\
\hline Very good & $n(\%)$ & 22 & 28.9 & 16 & 28 \\
\hline Good & $n(\%)$ & 50 & 65.8 & 38 & 66.7 \\
\hline Mediocre & $n(\%)$ & 4 & 5.3 & 3 & 5.3 \\
\hline \multicolumn{6}{|l|}{ BMI } \\
\hline Below $5^{\text {th }}$ percentile & $n(\%)$ & 14 & 18.4 & 13 & 22.8 \\
\hline $5^{\text {th }}-85^{\text {th }}$ percentile & $n(\%)$ & 50 & 65.8 & 39 & 68.4 \\
\hline Above $85^{\text {th }}$ percentile & $n(\%)$ & 12 & 15.8 & 5 & 8.8 \\
\hline Moderate activity (MET-min/week) & Mean (SD) & 245 & 31.4 & 220 & 60.1 \\
\hline \multicolumn{6}{|l|}{ Number of meals during of the day } \\
\hline 4 meals & $n(\%)$ & 63 & 82.9 & 50 & 87.7 \\
\hline 5 meals & $n(\%)$ & 13 & 17.1 & 7 & 12.3 \\
\hline
\end{tabular}

SD - standard deviation; SES - socioeconomic status; BMI - body mass index

TABLE 2. Amount of energy intake by gender and assigned BMI group [kcal/day] and percentage of energy intake from fats, protein, and carbohydrates

\begin{tabular}{|l|c|c|c|c|c|c|}
\hline \multirow{2}{*}{} & \multicolumn{3}{|c|}{ Boys/percentile } & \multicolumn{3}{c|}{ Girls/percentile } \\
\cline { 2 - 7 } & Below 5 & $5-85$ & Above 85 & Below 5 & $5-85$ & Above 85 \\
\hline Energy intake (kcal/day) & 2672 & 2573 & 3385 & 1660 & 2143 & 3076 \\
\hline \begin{tabular}{l} 
\% of energy intake from \\
\hline Fats
\end{tabular} & $42.2 \%$ & $35 \%$ & $37.3 \%$ & $35.9 \%$ & $36,6 \%$ & $33.1 \%$ \\
\hline Protein & $13.2 \%$ & $12.1 \%$ & $14.5 \%$ & $14.3 \%$ & $13.6 \%$ & $13.9 \%$ \\
\hline Carbohydrates & $44.6 \%$ & $52.9 \%$ & $48.2 \%$ & $49.8 \%$ & $49.8 \%$ & $53 \%$ \\
\hline
\end{tabular}

descriptive variable statistics, i.e. the average, the median ( $50^{\text {th }}$ percentile), and the $25^{\text {th }}$ and $75^{\text {th }}$ percentiles.

\section{ETHICAL CONSIDERATIONS}

The study was approved by the Bioethics Review Board of Bielsko-Biala (No: 2017/06/1/4), which is in accordance with the Declaration of Helsinki. All the participants (the examined children and their parents) provided informed written consent to take part in the research, participation in the study was voluntary, and the anonymity of the participants was maintained.

\section{RESULTS}

The socioeconomic status of the studied adolescents in both boys and girls groups in the majority of cases was very good or good. Only 5.3\% of boys' families and 5.3\% girls' families defined their socioeconomic status as mediocre. No families were found to be in a very bad financial situation (Table 1).

The results show varied intake of energy and individual fatty acids by children relative to their division into groups depending on BMI values.

\section{ENERGY - GIRLS AND BOYS}

In girls, the daily calorie intake was proportional to their division into groups according to BMI. The greater the daily intake of energy in each group, the higher the BMI value; however, this was not a simple proportional increase. Boys in group with the highest BMI percentile values had the highest intake of calories, while boys in the group with the lowest BMI percentile (below the $5^{\text {th }}$ percentile) had the same calorie intake as boys in group within the $5^{\text {th }}$ to $85^{\text {th }}$ BMI percentile bracket. A BMI value below the $5^{\text {th }}$ percentile could be the consequence of a significant amount of time being spent on physical activity.

In the studied group, fats were used to produce large amount of energy. In the group of boys with the lowest BMI percentile it was as high as $42.2 \%$. Only in girls from the group with BMI above $85^{\text {th }}$ percentile did the percentage of energy intake from fats constitute less than $35 \%$. Proteins provided $12.1-14.5 \%$ of the energy. The rest of the energy in the diet was provided by carbohydrates (Table 2). 
TABLE 3. The interquartile range (IQR) and median of saturated fatty acids intake in the studied groups of boys ( $\mathrm{g} /$ day)

\begin{tabular}{|c|c|c|c|c|}
\hline \multicolumn{5}{|c|}{ Saturated fatty acids } \\
\hline Fatty acid & Below $5^{\text {th }}$ percentile & $5^{\text {th }}-85^{\text {th }}$ percentile & Above $85^{\text {th }}$ percentile & P-value \\
\hline C $4: 0$ & $\begin{array}{c}0.59-0.80 \\
0.69\end{array}$ & $\begin{array}{c}0.17-0.90 \\
0.37\end{array}$ & $\begin{array}{c}0.24-0.45 \\
0.44\end{array}$ & \multirow[t]{12}{*}{$p<0.01$} \\
\hline C6:0 & $\begin{array}{c}0.49-0.61 \\
0.55^{*}\end{array}$ & $\begin{array}{c}0.24-0.59 \\
0.34^{* *}\end{array}$ & $\begin{array}{c}0.28-0.38 \\
0.37^{* * * *}\end{array}$ & \\
\hline $\mathrm{C} 8: 0$ & $\begin{array}{c}0.39-0.43 \\
0.41^{*}\end{array}$ & $\begin{array}{c}0.32-0.42 \\
0.34\end{array}$ & $\begin{array}{c}0.32-0.34 \\
0.33^{* * *}\end{array}$ & \\
\hline $\mathrm{C} 10: 0$ & $\begin{array}{c}1.04-1.14 \\
1.09^{*}\end{array}$ & $\begin{array}{c}0.76-0.98 \\
0.821\end{array}$ & $\begin{array}{c}0.80-0.82 \\
0.82^{* * *}\end{array}$ & \\
\hline $\mathrm{C} 12: 0$ & $\begin{array}{c}1.46-1.52 \\
1.49^{*}\end{array}$ & $\begin{array}{c}1.15-1.65 \\
1.19 \\
\end{array}$ & $\begin{array}{c}1.57-1.64 \\
1.57^{*-* *} \\
\end{array}$ & \\
\hline C14:0 & $\begin{array}{c}6.21-6.62 \\
6.41^{*}\end{array}$ & $\begin{array}{c}4.42-5.57 \\
5.01^{* *}\end{array}$ & $\begin{array}{c}5.55-5.69 \\
5.67^{* * * *}\end{array}$ & \\
\hline C15:0 & $\begin{array}{c}0.81-0.91 \\
0.86 \\
\end{array}$ & $\begin{array}{c}0.62-0.67 \\
5.01 \\
\end{array}$ & $\begin{array}{c}0.75-0.83 \\
0.81 \\
\end{array}$ & \\
\hline $\mathrm{C} 16: 0$ & $\begin{array}{c}29.62-31.93 \\
30.78^{*}\end{array}$ & $\begin{array}{c}20.72-27.30 \\
22.08^{* *}\end{array}$ & $\begin{array}{c}28.22-30.98 \\
30.88 \\
\end{array}$ & \\
\hline $\mathrm{C} 17: 0$ & $\begin{array}{c}0.41-0.54 \\
0.48\end{array}$ & $\begin{array}{c}0.34-0.42 \\
0.34\end{array}$ & $\begin{array}{c}0.35-0.38 \\
0.37\end{array}$ & \\
\hline C18:0 & $\begin{array}{c}14.03-16.84 \\
15.44^{*}\end{array}$ & $\begin{array}{c}6.63-11.71 \\
9.68^{* *}\end{array}$ & $\begin{array}{c}12.40-14.46 \\
14.45^{* * * *}\end{array}$ & \\
\hline $\mathrm{C} 20: 0$ & $\begin{array}{c}0.05-0.07 \\
0.06\end{array}$ & $\begin{array}{c}0.02-0.20 \\
0.04\end{array}$ & $\begin{array}{c}0.19-0.20 \\
0.19\end{array}$ & \\
\hline Total saturated fatty acids & $\begin{array}{c}55.25-61.50 \\
58.38^{*}\end{array}$ & $\begin{array}{c}36.77-51.56 \\
41.67^{* *}\end{array}$ & $\begin{array}{c}50.96-56.20 \\
56.18^{* * *}\end{array}$ & \\
\hline
\end{tabular}

* statistically significant difference relative to group below $5^{\text {th }}$ percentile and group $5^{\text {th }}-85^{\text {th }}$ percentile ** statistically significant difference relative to group $5^{\text {th }}-85^{\text {th }}$ percentile and group above $85^{\text {th }}$ percentile *** statistically significant difference relative to group below $5^{\text {th }}$ percentile and group above $85^{\text {th }}$ percentile a Pearson correlation

\section{SATURATED FATTY ACIDS (SFA) - BOYS}

Boys within the $5^{\text {th }}$ to $85^{\text {th }}$ BMI percentile bracket had the lowest intake of saturated fatty acids (41.67). At the same time, boys in group with a BMI percentile of below 5 had the highest intake of saturated fatty acids (58.38). This is connected to the type of diet followed.

In groups within the $5^{\text {th }}$ to $85^{\text {th }} \mathrm{BMI}$ percentile and with BMI above the $85^{\text {th }}$ percentile, the intake of medium-chain fatty acids was comparable (58.38 and 56.18). There was a similar pattern for the intake of the long chain acids C16:0 and C18:0. The highest intake of medium-chain fatty acids (MCFA) (C6:0, C8:0, C10:0 and C14:0) was recorded in the boys' group with BMI of below $5^{\text {th }}$ percentile. In the case of C12:0 acids, the highest intake was observed in the group with BMI above the $85^{\text {th }}$ percentile (1.57), while the lowest amount of these acids was noticed in the diet of boys in the group within the $5^{\text {th }}$ to $85^{\text {th }}$ BMI percentile (1.19) (Table 3).

\section{MONOUNSATURATED FATTY ACIDS (MUFA) - BOYS}

The highest intake of monounsaturated fatty acids (MUFA) was among boys in the group with BMI above the $85^{\text {th }}$ percentile (64.75). The lowest amount was found in the diet of boys with BMI in the $5^{\text {th }}$ to $85^{\text {th }}$ percentile bracket (34.67). The same pattern was found for the intake of C16:1 and C18:1 acids. For C15:1, C17:1, and C22:1 acids, however, the intake was proportionally opposite to the BMI value. The highest intake of these acids was among boys with the lowest BMI percentile, while the lowest intake of C15:1, C17:1, and C22:1 was recorded in boys from the group with the highest BMI percentile (Table 4).

\section{POLYUNSATURATED FATTY ACIDS (PUFA) - BOYS}

Boys with BMI values above the $85^{\text {th }}$ percentile had the highest intake of polyunsaturated fatty acids (16.36), which was reflected in their intake of C18:2 acid (13.85). However, boys in this group had the lowest intake of C22:6 (0.03), and a higher intake of C20:4 than boys within the $5^{\text {th }}$ to $85^{\text {th }}$ BMI percentile $(0.19)$. Boys with 
TABLE 4. The interquartile range (IQR) and median of unsaturated fatty acids intake in the studied groups of boys ( $\mathrm{g} /$ day)

\begin{tabular}{|c|c|c|c|c|}
\hline \multicolumn{5}{|c|}{ Monounsaturated fatty acids } \\
\hline Fatty acid & Below $5^{\text {th }}$ percentile & $5^{\text {th }}-85^{\text {th }}$ percentile & Above $85^{\text {th }}$ percentile & $P$-value ${ }^{a}$ \\
\hline $\mathrm{C} 14: 1$ & $\begin{array}{c}0.48-0.74 \\
0.61 \\
\end{array}$ & $\begin{array}{c}0.33-0.53 \\
0.44 \\
\end{array}$ & $\begin{array}{c}0.34-0.36 \\
0.35 \\
\end{array}$ & \multirow[t]{8}{*}{$p<0.01$} \\
\hline C15:1 & $\begin{array}{c}0.10-0.20 \\
0.15^{*}\end{array}$ & $\begin{array}{c}0.05-0.17 \\
0.08^{* *}\end{array}$ & $\begin{array}{c}0.06-0.07 \\
0.07^{* * *}\end{array}$ & \\
\hline C16:1 & $\begin{array}{c}2.59-3.58 \\
3.09^{*}\end{array}$ & $\begin{array}{c}2.21-2.99 \\
2.44^{* *}\end{array}$ & $\begin{array}{c}2.80-3.87 \\
3.84^{* *}\end{array}$ & \\
\hline C17:1 & $\begin{array}{c}0.21-0.41 \\
0.31 \\
\end{array}$ & $\begin{array}{c}0.09-0.32 \\
0.19 \\
\end{array}$ & $\begin{array}{c}0.11-0.16 \\
0.14^{* * * *}\end{array}$ & \\
\hline C18:1 & $\begin{array}{c}41.66-48.94 \\
42.80^{*}\end{array}$ & $\begin{array}{c}25.10-48.69 \\
31.17^{* *}\end{array}$ & $\begin{array}{c}51.38-59.46 \\
59.26^{* * *}\end{array}$ & \\
\hline $\mathrm{C} 20: 1$ & $\begin{array}{c}0.21-0.45 \\
0.33 \\
\end{array}$ & $\begin{array}{c}0.18-0.48 \\
0.33 \\
\end{array}$ & $\begin{array}{c}0.53-0.68 \\
0.67 \\
\end{array}$ & \\
\hline C22:1 & $\begin{array}{c}0.23-0.23 \\
0.23^{*}\end{array}$ & $\begin{array}{c}0.03-0.11 \\
0.05\end{array}$ & $\begin{array}{c}0.09-0.10 \\
0.10^{* * *}\end{array}$ & \\
\hline $\begin{array}{c}\text { Total monounsaturated } \\
\text { fatty acids }\end{array}$ & $\begin{array}{c}45.56-52.61 \\
47.59^{*}\end{array}$ & $\begin{array}{c}28.31-51.22 \\
34.67^{* *}\end{array}$ & $\begin{array}{c}55.35-64.76 \\
64.75^{* * * *}\end{array}$ & \\
\hline \multicolumn{5}{|c|}{ Polyunsaturated fatty acids } \\
\hline Fatty acid & Below $5^{\text {th }}$ percentile & $5^{\text {th }}-85^{\text {th }}$ percentile & Above $85^{\text {th }}$ percentile & P-value ${ }^{a}$ \\
\hline C18:2 & $\begin{array}{c}8.27-8.33 \\
8.30^{*} \\
\end{array}$ & $\begin{array}{c}7.25-12.14 \\
8.07^{* *} \\
\end{array}$ & $\begin{array}{c}12.57-13.86 \\
13.85 \\
\end{array}$ & \multirow[t]{8}{*}{$p<0.01$} \\
\hline C18:3 & $\begin{array}{c}1.60-2.41 \\
2.0 \\
\end{array}$ & $\begin{array}{c}0.90-1.71 \\
1.17 \\
\end{array}$ & $\begin{array}{c}1.79-2.05 \\
2.05 \\
\end{array}$ & \\
\hline C18:4 & $\begin{array}{l}0 \\
0 \\
\end{array}$ & $\begin{array}{l}0 \\
0 \\
\end{array}$ & $\begin{array}{c}0.006-0.01 \\
0.01 \\
\end{array}$ & \\
\hline C20:4 & $\begin{array}{c}0.26-0.4 \\
0.33^{*}\end{array}$ & $\begin{array}{c}0.07-0.26 \\
0.19^{* *} \\
\end{array}$ & $\begin{array}{c}0.26-0.41 \\
0.40\end{array}$ & \\
\hline $\mathrm{C} 20: 5$ & $\begin{array}{l}0-0.01 \\
0.007^{*}\end{array}$ & $\begin{array}{c}0-0.03 \\
0^{* *}\end{array}$ & $\begin{array}{l}0 \\
0\end{array}$ & \\
\hline C22:5 & $\begin{array}{c}0-0.014 \\
0.007\end{array}$ & $\begin{array}{c}0-0.005 \\
0^{* *}\end{array}$ & $\begin{array}{c}0 \\
0^{* * * *} \\
\end{array}$ & \\
\hline C22:6 & $\begin{array}{c}0.03-0.08 \\
0.06\end{array}$ & $\begin{array}{c}0.01-0.09 \\
0.09^{* * *}\end{array}$ & $\begin{array}{c}0.01-0.03 \\
0.03^{* * * *}\end{array}$ & \\
\hline $\begin{array}{l}\text { Total polyunsaturated } \\
\text { fatty acids }\end{array}$ & $\begin{array}{l}10.41-11.03 \\
10.72\end{array}$ & $\begin{array}{c}8.04-14.07 \\
10.40^{* *}\end{array}$ & $\begin{array}{c}14.65-16.37 \\
16.36^{* * *}\end{array}$ & \\
\hline
\end{tabular}

${ }^{*}$ statistically significant difference relative to group below $5^{\text {th }}$ percentile and group $5^{\text {th }}-85^{\text {th }}$ percentile

** statistically significant difference relative to group $5^{\text {th }}-85^{\text {th }}$ percentile and group above $85^{\text {th }}$ percentile

*** statistically significant difference relative to group below $5^{\text {th }}$ percentile and group above $85^{\text {th }}$ percentile

${ }^{a}$ Pearson correlation

the lowest BMI had a higher intake of the acid C20:4 (0.33) than the boys in group within the $5^{\text {th }}$ to $85^{\text {th }} \mathrm{BMI}$ percentile (0.40) (Table 4).

\section{SATURATED FATTY ACIDS (SFA) - GIRLS}

In girls, the intake of saturated fatty acids increased proportionally to the increase in BMI. The lowest intake was in the group of girls below the $5^{\text {th }}$ percentile (29.55), while the highest intake was in group above the $85 \mathrm{BMI}$ percentile (49.59). The same pattern appeared for the intake of saturated fatty acids with a chain length of 6 to
18 carbons. However, the highest intake of the fatty acid C20:0 was in girls assigned to the group with a BMI percentile of 5 to $85(0.16)$, while the lowest intake was in girls from the group with the lowest BMI percentile of 5 (0.04) (Table 5).

\section{MONOUNSATURATED FATTY ACIDS (MUFA) - GIRLS}

Intake of monounsaturated fatty acids in the girls was in direct proportion to BMI values. The highest intake was in girls from group with the highest BMI values 
TABLE 5. The interquartile range (IQR) and median of saturated fatty acids intake in the studied groups of girls ( $\mathrm{g} /$ day)

\begin{tabular}{|c|c|c|c|c|}
\hline \multicolumn{5}{|c|}{ Saturated fatty acids } \\
\hline Fatty acid & Below $5^{\text {th }}$ percentile & $5^{\text {th }}-85^{\text {th }}$ percentile & Above $85^{\text {th }}$ percentile & P-value $^{\mathrm{a}}$ \\
\hline C4:0 & $\begin{array}{c}0.30-0.32 \\
0.31\end{array}$ & $\begin{array}{c}0.23-0.32 \\
0.32\end{array}$ & $\begin{array}{c}0.32-0.37 \\
0.33\end{array}$ & \multirow[t]{12}{*}{$p<0.01$} \\
\hline C6:0 & $\begin{array}{c}0.19-0.20 \\
0.19 \\
\end{array}$ & $\begin{array}{c}0.18-0.20 \\
0.20^{* *}\end{array}$ & $\begin{array}{c}0.20-0.31 \\
0.31^{* * *}\end{array}$ & \\
\hline $\mathrm{C} 8: 0$ & $\begin{array}{c}0.16-0.18 \\
0.17^{*}\end{array}$ & $\begin{array}{c}0.18-0.20 \\
0.20^{* *}\end{array}$ & $\begin{array}{c}0.20-0.33 \\
0.30^{* * * *}\end{array}$ & \\
\hline $\mathrm{C} 10: 0$ & $\begin{array}{c}0.39-0.48 \\
0.39\end{array}$ & $\begin{array}{c}0.39-0.48 \\
0.48^{* *}\end{array}$ & $\begin{array}{c}0.52-0.76 \\
0.72^{* * *}\end{array}$ & \\
\hline $\mathrm{C} 12: 0$ & $\begin{array}{c}0.53-0.65 \\
0.58^{*} \\
\end{array}$ & $\begin{array}{c}0.61-0.65 \\
0.65^{* *}\end{array}$ & $\begin{array}{c}0.71-1.64 \\
1.32^{* * *} \\
\end{array}$ & \\
\hline $\mathrm{C} 14: 0$ & $\begin{array}{c}2.46-2.91 \\
2.47 \\
\end{array}$ & $\begin{array}{c}2.37-2.91 \\
2.91^{* *}\end{array}$ & $\begin{array}{c}3.08-5.34 \\
4.60^{* * * *}\end{array}$ & \\
\hline C15:0 & $\begin{array}{c}0.32-0.35 \\
0.35\end{array}$ & $\begin{array}{c}0.27-0.32 \\
0.32^{* *}\end{array}$ & $\begin{array}{c}0.34-0.74 \\
0.64^{* * *}\end{array}$ & \\
\hline $\mathrm{C} 16: 0$ & $\begin{array}{c}10.38-14.92 \\
14.92^{*}\end{array}$ & $\begin{array}{c}10.38-20.60 \\
20.50^{* *}\end{array}$ & $\begin{array}{c}11.75-28.66 \\
26.25^{* * *}\end{array}$ & \\
\hline $\mathrm{C} 17: 0$ & $\begin{array}{c}0.21-0.251 \\
0.21 \\
\end{array}$ & $\begin{array}{c}0.183-0.25 \\
0.24^{* *} \\
\end{array}$ & $\begin{array}{c}0.25-0.39 \\
0.35^{* * *}\end{array}$ & \\
\hline C18:0 & $\begin{array}{c}3.39-10.07 \\
10.03\end{array}$ & $\begin{array}{c}3.39-9.84 \\
9.82\end{array}$ & $\begin{array}{c}4.06-13.37 \\
11.81^{* * * *}\end{array}$ & \\
\hline $\mathrm{C} 20: 0$ & $\begin{array}{c}0.03-0.12 \\
0.04^{*}\end{array}$ & $\begin{array}{c}0.12-0.18 \\
0.16^{* *}\end{array}$ & $\begin{array}{c}0.09-0.16 \\
0.12^{* * *}\end{array}$ & \\
\hline Total saturated fatty acids & $\begin{array}{c}19.40-29.65 \\
29.55^{*}\end{array}$ & $\begin{array}{c}19.40-35.15 \\
34.15^{* *}\end{array}$ & $\begin{array}{c}21.81-52.11 \\
49.59^{* * *}\end{array}$ & \\
\hline
\end{tabular}

* statistically significant difference relative to group below $5^{\text {th }}$ percentile and group $5^{\text {th }}-85^{\text {th }}$ percentile ** statistically significant difference relative to group $5^{\text {th }}-85^{\text {th }}$ percentile and group above $85^{\text {th }}$ percentile

*** statistically significant difference relative to group below $5^{\text {th }}$ percentile and group above $85^{\text {th }}$ percentile

a Pearson correlation

(above the $85^{\text {th }}$ percentile) (35.97). The lowest intake was in girls from the group with the lowest BMI values (below the $5^{\text {th }}$ percentile) (25.71). These results were reflected in the intake of individual monounsaturated fatty acids. Intake of C14:1, C15:1, C16:1, and C18:1 acids increased in equal proportion to the assigned BMI group (Table 6).

\section{POLYUNSATURATED FATTY ACIDS (PUFA) - GIRLS}

The intake of polyunsaturated fatty acids in girls was lowest in group with the lowest BMI values (below the $5^{\text {th }}$ percentile) (5.41). Between groups with a BMI percentile of 5 to 85 and with BMI above the $85^{\text {th }}$ percentile, however, no statistical difference was noted in the intake of these fatty acids. This was reflected in the intake of C18:2 acids. Meanwhile, the intake of $\mathrm{C} 22: 6$ acid was greatest amongst girls with BMI values below the $5^{\text {th }}$ percentile (1.87) (Table 6).

\section{DISCUSSION}

The research has shown that the BMI coefficient in children is related to the daily intake of energy. The higher a child's BMI coefficient, the greater their daily intake of energy. These results are consistent with data in the literature from studies regarding children's diets $[1,4,5$, $31,32]$. In the current study, we focused on detailed analysis of selected fatty acids in the diets of 15-year-olds with various BMI scores.

On the basis of the results obtained from the research, it was elucidated that the average daily intake of fatty acids in both the boys and girls was too high. The recommended fat intake for 13- to 15-year-old boys and girls is $93 \mathrm{~g}$ per day and $82 \mathrm{~g}$ per day, respectively [29]. In the study, intake of fatty acids was $87-137 \mathrm{~g}$ per day for boys and 61-102 g per day for girls. This is far too much because it can lead to excess weight and obesity in adult life as well as increased risk of cardiovascular diseases and cancer.

One limitation to our study was that the study group was small. However, the study covered $100 \%$ of the pupils of the same age living in the village where the study was conducted. The literature shows no studies that include analysis of the intake of fatty acids among children and adolescents.

Research conducted amongst Polish young people aged 16-18 years residing in rural areas near Żywiec has shown that boys as well as girls consumed fats within the limits of the recommended values. 
TABLE 6. The interquartile range (IQR) and median of unsaturated fatty acids intake in the studied groups of girls ( $\mathrm{g} /$ day)

\begin{tabular}{|c|c|c|c|c|}
\hline \multicolumn{5}{|c|}{ Monounsaturated fatty acids } \\
\hline Fatty acid & Below $5^{\text {th }}$ percentile & $5^{\text {th }}-85^{\text {th }}$ percentile & Above $85^{\text {th }}$ percentile & P-value ${ }^{a}$ \\
\hline $\mathrm{C} 14: 1$ & $\begin{array}{c}0.25-0.33 \\
0.27 \\
\end{array}$ & $\begin{array}{c}0.25-0.33 \\
0.33^{* *}\end{array}$ & $\begin{array}{c}0.33-0.40 \\
0.36^{* * *}\end{array}$ & \multirow[t]{8}{*}{$p<0.01$} \\
\hline C15:1 & $\begin{array}{c}0.064-0.065 \\
0.064\end{array}$ & $\begin{array}{c}0.05-0.07 \\
0.065^{* *}\end{array}$ & $\begin{array}{c}0.06-0.08 \\
0.07\end{array}$ & \\
\hline C16:1 & $\begin{array}{c}1.35-1.67 \\
1.64^{*}\end{array}$ & $\begin{array}{c}1.35-2.67 \\
2.66^{* *}\end{array}$ & $\begin{array}{c}1.35-2.85 \\
2.58^{* * *}\end{array}$ & \\
\hline C17:1 & $\begin{array}{c}0.08-0.30 \\
0.09 \\
\end{array}$ & $\begin{array}{c}0.14-0.30 \\
0.16\end{array}$ & $\begin{array}{c}0.13-0.28 \\
0.16 \\
\end{array}$ & \\
\hline C18:1 & $\begin{array}{c}19.66-23.39 \\
23.31^{*} \\
\end{array}$ & $\begin{array}{c}19.66-27.32 \\
27.22^{* *}\end{array}$ & $\begin{array}{c}20.44-57.38 \\
31.96^{* * *}\end{array}$ & \\
\hline $\mathrm{C} 20: 1$ & $\begin{array}{c}0.24-1.31 \\
0.25\end{array}$ & $\begin{array}{c}0.29-1.31 \\
0.47\end{array}$ & $\begin{array}{c}0.35-1.11 \\
0.51 \\
\end{array}$ & \\
\hline C22:1 & $\begin{array}{c}0.01-1.67 \\
0.01\end{array}$ & $\begin{array}{c}0.08-1.67 \\
0.23\end{array}$ & $\begin{array}{c}0.15-1.31 \\
0.25\end{array}$ & \\
\hline $\begin{array}{c}\text { Total monounsaturated } \\
\text { fatty acids }\end{array}$ & $\begin{array}{c}24.72-25.73 \\
25.71^{*}\end{array}$ & $\begin{array}{c}24.72-30.84 \\
30.64^{* *}\end{array}$ & $\begin{array}{c}24.72-61.64 \\
35.97^{* * * *}\end{array}$ & \\
\hline \multicolumn{5}{|c|}{ Polyunsaturated fatty acids } \\
\hline Fatty acid & Below $5^{\text {th }}$ percentile & $5^{\text {th }}-85^{\text {th }}$ percentile & Above $85^{\text {th }}$ percentile & P-value ${ }^{a}$ \\
\hline C18:2 & $\begin{array}{c}3.42-15.18 \\
3.48^{*} \\
\end{array}$ & $\begin{array}{c}8.98-15.18 \\
12.28 \\
\end{array}$ & $\begin{array}{c}9.38-14.87 \\
13.93^{* * *} \\
\end{array}$ & \multirow[t]{8}{*}{$p<0.01$} \\
\hline C18:3 & $\begin{array}{c}0.79-1.91 \\
0.89 *\end{array}$ & $\begin{array}{c}0.98-1.91 \\
1.81^{* *} \\
\end{array}$ & $\begin{array}{c}1.80-2.67 \\
2.02^{* * * *}\end{array}$ & \\
\hline C18:4 & $\begin{array}{c}0.30-0.30 \\
0.30^{*} \\
\end{array}$ & $\begin{array}{c}0.01-0.30 \\
0.02^{* *}\end{array}$ & $\begin{array}{c}0.30-0.30 \\
0.30 \\
\end{array}$ & \\
\hline C20:4 & $\begin{array}{c}0.19-0.21 \\
0.19 \\
\end{array}$ & $\begin{array}{c}0.14-0.21 \\
0.21 \\
\end{array}$ & $\begin{array}{c}0.11-0.25 \\
0.23 \\
\end{array}$ & \\
\hline $\mathrm{C} 20: 5$ & $\begin{array}{c}1.10-1.10 \\
1.10 \\
\end{array}$ & $\begin{array}{c}1.100-1.10 \\
1.10 \\
\end{array}$ & $\begin{array}{c}0.07-0.10 \\
1.10^{* * *}\end{array}$ & \\
\hline C22:5 & $\begin{array}{c}0.23-0.24 \\
0.23 \\
\end{array}$ & $\begin{array}{c}0.23-0.24 \\
0.23 \\
\end{array}$ & $\begin{array}{c}0.006-0.23 \\
0.21^{* * *}\end{array}$ & \\
\hline C22:6 & $\begin{array}{c}1.87-1.88 \\
1.87^{*} \\
\end{array}$ & $\begin{array}{c}0.07-1.87 \\
0.09 \\
\end{array}$ & $\begin{array}{c}0.02-1.87 \\
0.09^{* * * *}\end{array}$ & \\
\hline $\begin{array}{l}\text { Total polyunsaturated } \\
\text { fatty acids }\end{array}$ & $\begin{array}{c}4.41-18.82 \\
5.41^{*}\end{array}$ & $\begin{array}{c}10.19-20.82 \\
14.73\end{array}$ & $\begin{array}{c}11.65-19.84 \\
16.89^{* * * *}\end{array}$ & \\
\hline
\end{tabular}

${ }^{*}$ statistically significant difference relative to group below $5^{\text {th }}$ percentile and group $5^{\text {th }}-85^{\text {th }}$ percentile

** statistically significant difference relative to group $5^{\text {th }}-85^{\text {th }}$ percentile and group above $85^{\text {th }}$ percentile

*** statistically significant difference relative to group below $5^{\text {th }}$ percentile and group above $85^{\text {th }}$ percentile

a Pearson correlation

Stachura et al. did not give the size of the study group but only the number of dietary records received. However, this research did not include the analysis of the BMI values of youths. For girls, BMI values were proportionate to the intake of saturated and monounsaturated fatty acids. In boys, however, this was true for the groups of between the $5^{\text {th }}$ and $85^{\text {th }}$ BMI percentiles, and above the $85^{\text {th }}$ BMI percentile [33].

These results are consistent with data from the literature indicating that people with a high BMI have a significantly higher intake of fats [5-8, 34-36].
The caloric value of food was not different for boys in the BMI group below the $5^{\text {th }}$ percentile

from that of the group of boys in the $5-85^{\text {th }}$ BMI percentile bracket. However, boys with a BMI below the $5^{\text {th }}$ percentile had a statistically significant higher intake of saturated (58.38) fatty acids. The influence of the increased intake of fatty acids on low BMI value can be explained to some degree by the detailed composition of fatty acids in the diets of the boys in these 2 groups. In comparison to the $5-85^{\text {th }} \mathrm{BMI}$ percentile group, boys with a BMI below the $5^{\text {th }}$ percentile had a significantly higher 
intake of monounsaturated fatty acids, in particular C18:1 and C16:1. These acids stimulate thermogenesis; thus, their secondary effect can be to increase energy demand [37-39], which ultimately leads to a drop in body mass. Similar results were reported by Moussavi et al. [31] in their analysis of the diet of 15-year-old girls. However, they described only the relation between BMI and the total amount of monounsaturated fatty acids (MUFA) in the diet without analysing the influence of individual MUFAs on BMI. One interesting aspect is the direction of change in the intake of MCFAs in both boys and girls. Amongst the boys, a higher intake of MCFAs was observed in the group with the highest BMI values (64.75).

Similar tendencies were not observed in the groups of girls, in the case of which it was 25.71 for girls with the lowest BMI value and 35.71 for girls with the highest BMI value.

The causes of the increase in MCFA intake in the above-mentioned groups of boys undoubtedly vary. While the increase in MCFA in the group with the lowest BMI generally results from the higher intake of fat, in the group with the highest BMI values the percentage of fat in the diet increases due to proteins, which may be a compensatory reaction by the body.

Research of youths from the vicinity of Żywiec did not reveal such a high intake of monounsaturated fatty acids amongst boys, which amounted to 40.9. The intake of monounsaturated fatty acids amongst girls, according to Stachura et al. [33], totalled 34.2. In our own research it was lower (25.71) or similar (35.97) depending on the BMI value reached in studied girls. From the metabolic point of view, however, the differences in the amounts of main representatives of n-3 (C18:3) and n-6 (C18:2) are more significant, because they are not synthesized in the human body and they must be provided from the diet.

This is also true for the ratio of n-6 (C18:2) to $n-3$ (C18:3) in the diet, which for girls was 3.9:1 in the group with the lowest BMI percentile, 6.78:1 in the group within the $5^{\text {th }}$ to $85^{\text {th }} \mathrm{BMI}$ percentile, and 6.89:1 in the group with the highest BMI percentile. For boys, the ratios were 5.18:1 in group with the lowest BMI percentile, 6.89:1 in group within the $5^{\text {th }}$ to $85^{\text {th }}$ BMI percentile, and $6.75: 1$ in group with the highest BMI percentile. The proportion of n- 6 to n-3 should be 2:1 - 5:1. Consequently, only groups with the lowest BMI value reached the normal intake of these acids. Also, the $\mathrm{n}-6 / \mathrm{n}-3$ ratio has been examined as a potential risk factor in cardiovascular diseases or as a factor that increases the risk of oxidative stress and the development of obesity.

The research showed that in the modern diet, fats account for as much as $40 \%$ of daily energy requirements, while the proportion of fatty acids n- 6 and n-3 amounted to over 10:1. The optimal intake of EPA and DHA is $1 \mathrm{~g}$ per day. The current research has shown that in the group of girls with BMI below the 5th percentile the intake of EPA and DHA was very high. This may result from preparing meals high in oil. Very high intake of EPA and DHA leads to increased cholesterol levels [40, 41].

The main dietary source of $n-3$ acids is fish, while in Poland also rapeseed oil. The source of n-6 acids is corn oil, sunflower oil, and rapeseed oil. Furthermore, rapeseed oil has a normal n-6/n-3 ratio of around $2: 1$. The source of EPA and DHA is fish and oils [30].

A low intake of unsaturated fatty acids is caused by too infrequent consumption of fish, and the preparation of dishes using margarine. Inappropriate dietary habits also include excessive consumption of saturated fatty acids found in yellow cheeses, eggs, and milk - products that young people are happy to consume [26].

Numerous studies have shown unhealthy habits in children's nutrition. The problem affects a large proportion of children worldwide and is showing a tendency for rapid progression. Unfortunately, numerous costly campaigns promoting a healthy diet have shown limited effect. While the medical and social consequences of this trend may be predicted for the current generation, they cannot be estimated for future generations.

\section{CONCLUSIONS}

The normal dietary intake of fatty acids n-3 and n- 6 occurred amongst 15-year-old boys and girls with BMI below the $5^{\text {th }}$ percentile.

In order to achieve a properly balanced diet, it is necessary to increase the intake of monounsaturated fatty acids and reduce the intake of saturated fatty acids at the same time. The diet should also be appropriate to the child's level of physical activity and to their energy requirements.

\section{DISCLOSURE}

The authors declare no conflict of interest.

\section{REFERENCES}

1. Berkey CS, Rockett HR, Field AE, et al. Activity, dietary intake, and weight changes in a longitudinal study of preadolescent and adolescent boys and girls. Pediatrics 2000; 105: E56.

2. Carlson JA, Crespo NC, Sallis JF, et al. Dietary-related and physical activity-related predictors of obesity in children: a 2-year prospective study. Child Obes 2012; 8: 110-115.

3. Haerens L, Vereecken C, Maes L, De Bourdeaudhuij I. Relationship of physical activity and dietary habits with body mass index in the transition from childhood to adolescence: a 4-year longitudinal study. Public Health Nutr 2010; 10A: 1722-1728.

4. Thompson OM, Ballew C, Resnicow K, et al. Dietary pattern as a predictor of change in BMI z-score among girls. Int J Obes 2006; 1: 176182.

5. Tucker LA, Seljaas GT, Hager RL. Body fat percentage of children varies according to their diet composition. J Am Diet Assoc 1997; 97: 981-986.

6. Duvigneaud N, Wijndaele K, Matton L, et al. Dietary factors associated with obesity indicators and level of sports participation in Flemish adults: a cross-sectional study. Nutr J 2007; 6: 26. 
7. Randi G, Pelucchi C, Gallus S, et al. Lipid, protein and carbohydrate intake in relation to body mass index: an Italian study. Public Health Nutr 2007; 10: 306-310.

8. Millar L, Rowland B, Nichols M, et al. Relationship between raised $\mathrm{BMI}$ and sugar sweetened beverage and high fat food consumption among children. Obesity 2014; 22: E96-E103.

9. Auestad N, Scott DT, Janowsky JS, et al. Visual, cognitive, and language assessments at 39 months: a follow-up study of children fed formulas containing long-chain polyunsaturated fatty acids to year of age. Pediatrics 2003; 112: 177-183.

10. Bobiński R, Mikulska M, Mojska H, Ulman-Włodarz I. The Dietary Composition of Women Who Delivered Healthy Full-Term Infants, Preterm Infants, and Full-Term Infants Who Were Small for Gestational Age. Biol Res Nurs 2015; 17: 495-502.

11. Alvino G, Cozzi V, Radaelli T, et al. Maternal and fetal fatty acid profile in normal and intrauterine growth restriction pregnancies with and without preeclampsia. Pediatr Res 2008; 64: 615-620.

12. Singh M. Essential fatty acids, DHA and human brain. Indian J Pediatr 2005; 72: 239-242.

13. Walczewska A, Stępień T, Bewicz-Binkowska D, Zgórzyńska E. The role of docosahexaenoic acid in neuronal function. Post Hig Med Dosw 2011; 65: 314-327.

14. Hoppenbrouwers T, Cveji'c Hogervorst JH, et al. Long Chain Polyunsaturated Fatty Acids (LCPUFAs) in the Prevention of Food Allergy. Front Immunol 2019; 22: 1118.

15. Larsson SC, Kumlin M, Ingelman-Sundberg M, Wolk A. Dietary long-chain n-3 fatty acids for the prevention of cancer: a review of potential mechanisms. Am J Clin Nutr 2004; 79: 935-945.

16. Liu J, Ma DW. The role of $n-3$ polyunsaturated fatty acids in the prevention and treatment of breast cancer. Nutrients 2014; 6: 5184-5223.

17. Jan S, Guillou H, D’Andrea S, et al. Myristic acid increases 6-desaturase activity in cultured rat hepatocytes. Reprod Nutr Dev 2004; 44: 131-140.

18. Rioux V, Catheline D, Legrand P. Dietary myristic acid at physiologically relevant levels increases the tissue content of C20:5n-3 and C20:3n-6 in the rat. Repr Nutr Dev 2005; 45: 599-612.

19. Tachibana S, Sato K, Cho Y, et al. Octanoate reduces very low-density lipoprotein secretion by decreasing the synthesis of apolipoprotein $B$ in primary cultures of chicken hepatycytes. Biochim Biophys Acta 2005; 1737: 36-43.

20. Legrand P, Catheline D, Rioux V, Durand G. Lauric acid is desaturated to C12:1 n-3 by rat liver homogenate and hapatocytes. Lipids 2002; 37: 569-572.

21. Legrand P, Rioux V. The complex and important cellular and metabolic functions of saturated fatty acids. Lipids 2010; 45: 941-946.

22. Sratovci D, Aquilera M, MacSharry J, Melgar S. The Impact of Western Diet and Nutrients on the Microbiota and Immune Response at Mucosal Interfaces. Front Immunol 2017; 28: 838.

23. Calder PC, Dangour AD, Diekman C, et al. Essential fats for future health. Proceedings of the $9^{\text {th }}$ Unilever Nutrition Symposium, 26-27 May 2010.

24. Küllenberg D, Taylor LA, Schneider M, Massing U. Health effects of dietary phospholipids. Lipids Health Dis 2012; 11: 3.

25. Zalewska M, Zubrycki A, Sosnowski Z, et al. Selected nutritional behaviors and physical activity among elementary school children. Prog Health Sci 2017; 7: 131-137.

26. Pollok-Waksmańska W. Eating habits and the way of life elements influent on the nutritional status of children and youth living in the rural areas. Wydawnictwo Naukowe ATH Bielsko-Biała 2020.

27. Szponar L, Wolnicka K, Rychlik E. Album of photographs of food products and dishes. National Food and Nutrition Institute. Poland, Warsaw 2010.

28. Waksmańska W, Bobiński R, Ulman-Włodarz I, et al. The dietary composition of women who delivered preterm and full-term infants. Appl Nurs Res 2017; 35: 13-17.
29. World Health Organization. Obesity. 2007. www.who.int/topics/ obesity/en/ 15.09.2020.

30. Jarosz M. The standard of nutrition for the Polish population amendment. National Food and Nutrition Institute. Poland, Warsaw 2012.

31. Moussavi N, Gavino V, Receveur O. Is obesity related to the type of dietary fatty acids? An ecological study. Public Health Nutr 2008; 11: 1149-1155.

32. Elliott SA, Truby H, Lee A, et al. Associations of body mass index and waist circumference with: energy intake and percentage energy from macronutrients, in a cohort of Australian children. Nutr J 2011; 10: 58 .

33. Stachura A, Pisulewski PM, Kopeć A, et al. Assessing the dietary intake level of total fats and fatty acids by high school students living in rural areas in the Beskid Żywiecki region. Żywn Nauka Technol Jakość 2009; 5: 119-131.

34. Maffeis C, Pinelli L, Schutz Y. Fat intake and adiposity in 8 to 11-year-old obese children. Int J Obes Relat Metab Disord 1996; 20: $170-174$.

35. Hill JO, Melanson EL, Wyatt HT. Dietary fat intake and regulation of energy balance: implications for obesity. J Nutr 2000; 130: 284S-288S.

36. Ahluwalia N, Ferrières J, Dallongeville J, et al. Association of macronutrient intake patterns with being overweight in a population-based random sample of men in France. Diabetes Metab 2009; 35: 129-136.

37. Takeuchi H, Matsuo T, Tokuyama K, et al. Diet-induced thermogenesis is lower in rats fed a lard diet than in those fed a high oleic acid safflower oil diet, a safflower oil diet or a linseed oil diet. J Nutr 1995; 125: 920-925.

38. Kien CL, Bunn JY, Ugrasbul F. Increasing dietary palmitic acid decreases fat oxidation and daily energy expenditure. Am J Clin Nutr 2005; 82: 320-326.

39. Kien CL, Bunn JY. Gender alters the effects of palmitate and oleate on fat oxidation and energy expenditure. Obesity 2008; 1: 29-33.

40. Dutkowska A, Rachoń D. Role of n-3 and n-6 unsaturated fatty acids in the prevention of cardiovascular diseases. Chor Serca Naczyn 2015; 12: 154-159.

41. Kolanowski W. Functions and metabolic transformations of omega-3 polyunsaturated fatty acids in human body. Bromat Chem Toksykol 2013; 3: 267-272. 